\title{
To the issue of third edition of the Red List of the Kemerovo region
}

\author{
Svetlana Sheremetova ${ }^{*}$ and Irina Khrustaleva \\ Department “Kuzbass Botanical Garden”, Federal State Budget Scientific Institution «The Federal \\ Research Center of Coal and Coal Chemistry of Siberian Branch of the Russian Academy of \\ Sciences», 650065, Leningradsky av., 10, Kemerovo, Russia
}

\begin{abstract}
Recent systematic floristic researches cause the necessity of changes and amendments in the lists of rare and disappearing plants, included in the Red Book of the Kemerovo region of first (2000) and second (2012) edition. New recommendations for third edition are proposed. 142 species will be included into third edition of the Red Book of the Kemerovo region 32 more species will be added for the first time, 18 species will be removed. Only 46 species will keep both the presence and statuses (categories) of a rarity; 34 species, presented in all three lists, will change their category (status).
\end{abstract}

Botanical researches in Kuzbass began in the first half of the 18th century; during 300 years history they had both periods of rising and periods of recession. A.V. Kuminova in monograph "Vegetation of the Kemerovo region" [1] noted that by the middle of the 20th century the Kemerovo region was one of the most popular for investigations regions of Siberia. I.M. Krasnoborov [2] wrote that in the second half of XX century the interest in Kemerovo region botanical researches was lost. Nevertheless, by the beginning of the $21 \mathrm{st}$ century collected materials and capacity of scientific community allowed to prepare for publication the Red Book of the Kemerovo Region [3] (in 2000), and the «Plant identification guide» (in 2001) [4]. I.M. Krasnoborov [2] notes that work on writing «Plant identification guide» was very difficult, as there were very few floristic publications concerning some groups of plants of the region, and the herbarium collected across Kuzbass was not full. Moreover, the collection was storaged in different Herbariums of the country.

Regular floristic investigations on the territory of the region, carried out by researchers of the Kuzbass botanical garden [5], began in 2002. The most complete Herbarium (KUZ) of the Kemerovo region with more than 16000 samples of vascular plants [6] of Kuzbass was created.

New information about known location number, new locations, and new species [7-9] allowed to add amendments to the list of rare plants in second edition of the Red Book of the Kemerovo region (2012) [10]. 29 species were removed from the list of rare and disappearing plants of the Kemerovo region [3], the status was changed for 29 species, 27 species were included in the list for the first time (14 of them were new to the region). The

* Corresponding author: ssheremetova@rambler.ru 
section of resource plants was excluded. 9 new families represented by the following species: Aristolochiaceae (Asarum europaeum L.), Asparagaceae (Asparagus pallasii Miscz.), Convolvulaceae (Convolvulus chinensis Ker-Gawl.), Fumariaceae (Corydalis solida subsp. subremota (M. Popov) Peschkova), Linaceae (Linum perenne L., and in the third the edition - Linum altaicum Ledeb. ex Juz.), Polygalaceae (Polygala tenuifolia Willd.), Saxifragaceae (Mitella nuda L.), Cupressaceae (Juniperus communis L.), Athyriaceae (Cystopteris altajensis Gureeva). The species list of some families was completely changed: for example, Allium ramosum L. and Allium vodopjanovae Friesen were added instead of Allium rubens Schrader ex Willd. and Allium clathratum Ledeb. 4 families with the following species were removed: Apocynaceae (Apocynum lancifolium Russanov), Gentianaceae (Gentiana septemfida Pall.), Limoniaceae (Limonium gmelinii (Willd.) O. Kuntze), Huperziaceae (Huperzia selago Bernh. ex Schrank et Mart).

As results of work of researchers from Kuzbass Botanical Garden (S.A. Sheremetova, A.N Kupriyanov.), Central Siderian Botanical Garden (N.N. Lashchinsky), Tomsk State University (A.L. Ebel), Kemerovo State University (A.V. Klimov) recommendations to the third edition of the Red List of the Kemerovo region were created.

For inclusion in the list of rare and disappearing plants of the Kemerovo region 32 species are recommended (the recommended status is given in brackets): Astragalus vaginatus Pall. (1), Astragalus austriacus Jacq. (2), Stipa lessingiana Trin. et Rupr. (2), S. praecapillata Alechin (2), Agropyron kazachstanikum (Tzvel.) Peschkova (3), Astragalus follicularis Pall. (3), Thellumgiella salsuginea (Pallas) O.E. Schulz (3), Blysmus rufus (Hudson) Link (3), Arctous erythrocarpa Small (3), Sajanella monstrosa (Willd. ex Sprengel) Sojak (3), Rhodiola quadrifida (Pall.) Fisch.et Mey. (2)., Linum altaicum Ledeb. ex Juz. (1), Carex alba Scop. (3), C. buxbaumii Wahlenb. (2), C. serotina Merat (2), C. sedakowii S.A. Meuyeg of ex Meinsh. (3), Potentilla erecta (L.) Raeuschel (2), Anemonidium dichotomum (L.) Holub (3), Cypripedium venthcosum Sw. (3), Gymnadenia conopsea (L.) R. Br. (3), Herminium monorchis (L.) R. Br. (3), Botrychium virginianum (L.) Sw. (3). With a part of new types such families as also are included in the list: Menyanthaceae (Nymphoides peltata (S.G. Gmel.) Kuntze (3)), Salicaceae (Populus alba L. (3)), Chenopodiaceae (Atriplex fera (L.) Bunge (1), Krascheninnikovia ceratoides (L.) Gueldenst. (1)), Portulacaceae (Claytonia Joanneana Roem. et Schult. (3)), Lentibulariaceae (Utricularia minor L. (2)), Thelypteridaceae (Oreopteris limbosperma (All.) Holub. (3)), Woodsiaceae (Woodsia pinnatifida (Fomin) Schmakov (3), W. heterophylla (Turcz. ex Fomin) Schmakov (2) W. calcarea (Fomin) Schmakov (3)).

Change of category (status) of rarity is recommended to 15 species: Lupinaster eximius (Steph. ex Serg.) C. Presl. (from $2 \rightarrow$ to 1), Rhododendron aureum Georgi (3 $\rightarrow$ $1)$, Cerastium maximum L. $(3 \rightarrow 2)$, Geranium robertianum L. $(2 \rightarrow 3)$, Bupleurum bicaule Helm $(2 \rightarrow 1)$, Trinia ramosissima Ledeb. $(2 \rightarrow 1)$, Erysimum flavum subsp. altaicum (C.A. Meyer) Polozhij $(2 \rightarrow 3)$, Fritillaria meleagroides Patrin ex Schult.et Schult. $(2 \rightarrow$ 3), Tulipa patens Agardh ex Shult.et Shult. $(1 \rightarrow 2)$, Scrophularia umbrosa Dumort. $(1 \rightarrow$ 3), Dactylorhiza russowii (Klinge) Holub $(2 \rightarrow 3)$, Viola dissecta Ledeb.(2 $\rightarrow 3)$, Ephedra monosperma C. A. Mey. $(2 \rightarrow 3)$, Ophioglossum vulgatum L. $(1 \rightarrow 3)$, Hedysarum turczaninovii Peschkova $(3 \rightarrow 2)$.

We recommend excluding from third edition of 18 species of vascular plants.: Artemisia pontica L, Artemisia santolinifolia Turcz. ex Bess., Corydalis solida subsp. subremota (M. Popov) Peschkova, Dactylorhiza fuchsii (Druce) Soó, D. longifolia (L. Neum.)Aver., Elatine triandra Schkuhr, Hordeum roshevitzii Bowden, Lindernia procumbens (Krock.) Borb, Myosotis jenissejrnsis O. D. Nikiforova, Paeonia hybrida Pall. Primula patens (Turcz.)E. Busch (P. sieboldii E. Morren), Pyrola media Sw., Rhododendron Ledebourii Pojark., Spiraea crenata L., Trapa natans L., Viola incisa Turcz. Scirpus validus Vahl, Lathyrus krylovü Serg. Some of them are not confirmed by herbarium collection; some 
species were found in good condition of large local populations, some taxa are still dubious in the modern systematics. For example, Corydalis solida subsp. subremota was included into the Red Book (2012) with rare indication of locations near village Ankimo-Annenka according to the herbarium of Kemerovo State University. Recent researches showed no finding near this village, but this species is widespread in Tyazhin river basin: state of its populations allow to recommend it for removal from list. Some families in the Red Book of the Kemerovo region (2012) were presented by one species, and in the third edition, after the accepted changes five families will be removed: Elatinaceae, Paeoniaceae, Primulaceae, Trapaceae, Fumariaceae.

Despite the accepted changes and new recommendions, 46 species keep not only the positions in the list of rare and disappearing plants, but also the statuses (categories) of rarity. 34 species presented in all three lists of the Red Books changed categories, the status of a rarity was increased for 11 of them.

Thus, the Red Book of the Kemerovo region included 128 species of vascular plants in first and second editions, 142 species were recommended for third edition. In third edition $56 \%$ of the species is supposed to remain on the list, but only $32 \%$ keep the category and the rarely status. We consider that the accumulation of information about rare plants species allows to reduce the subjectivity of rare species and rare species status.

\section{Acknowledgment}

Work is performed within the State task № 0352-2019-0015, with involvement of funds of USI «Herbarium of the Kuzbass botanical garden» (KUZ)

\section{References}

1. A.V. Kuminova. The Vegetation of the Kemerovo region (Novosibirsk, 1950)

2. I.M. Krasnoborov, Botanical research in Siberia and Kazakhstan, 12 (2006)

3. Red Book of the Kemerovo region (Kemerovskoe kniznoe izdatelstvo, Kemerovo, 2000)

4. Plant identification guide of the Kemerovo region (Publishing House SB RAS, Novosibirsk, 2001)

5. S.A. Scheremetova, Flora of the Tom River Basin: composition, structure, transformation, spatial organization (Tomsk, 2016)

6. I.A. Khrustaleva, Botanical collections - a national treasure of Russia, 285 (2015)

7. T.E. Buko, S.A. Scheremetova, A.L. Ebel, Botanical research in Siberia and Kazakhstan, 15 (2009)

8. S.A. Scheremetova, A.L. Ebel, T.E. Buko, Turczaninowia, 14(1) (2011)

9. A.L. Ebel, Turczaninowia, 5(2) (2002)

1. Red Book of the Kemerovo region (Azya print, Kemerovo, 2012) 